\title{
The Comparison between Two Hypnoteaching Models in Mathematics Teaching and Learning
}

\author{
Ja'faruddin ${ }^{1,2^{*}}$, Hamzah Upu ${ }^{1}$, Chen Wen-Haw ${ }^{2}$, Daniel Chia-En Teng ${ }^{2}$ \\ ${ }^{1}$ Universitas Negeri Makassar, INDONESIA \\ ${ }^{2}$ Tunghai University, TAIWAN

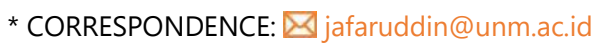

\begin{abstract}
This study compares two hypnoteaching models used to teach students mathematics. Due to the increase in the use of these models, further vigorous studies are needed to verify their effects. This is a quasi-experiment research conducted to compare the use of the hypnoteaching model using three classes of students. The first, second, and third classes of 15, 13, and 15 students were randomly taught with the Erickson Hypnoteaching Model (Erickson-HM), Elman Hypnoteaching Model (Elman-HM), and conventional non-hypnoteaching model (CM), respectively. The results showed that students in the Erickson-HM group outperformed others, while those in the ElmanHM group performed better than their peers in the CM group. In addition, students in both hypnoteaching groups had higher motivation in learning than those in the CM group. Therefore, discussions and suggestions on hypnoteaching of math were proposed.
\end{abstract}

Keywords: hypnoteaching, Erickson Hypnoteaching Model, Elman Hypnoteaching Model, Mathematics education

\section{INTRODUCTION}

The advancement in modern technology has led to an increase in the natural and effective use of resources. Technology has significantly improved human lives in terms of entertainment, communication, internet connection, and other social media such as Facebook, WhatsApp, Line, Skype, etc. This growth in technology led to the inception of the "digital generation" (Hockly, 2011).

Besides the various benefits associated with state-of-the-art technology, this development also has some adverse effects on how students receive information. Many students have become visual learners (Smaldino, Lowther, \& Russell, 2008), by absorbing information from the screen (Lytras, Gasevic, Ordonez de Pablos, \& Huang, 2008) through interactive animation, narration, and sound (Bester \& Brand, 2013). According to research, regular teaching using animated screens tend to reduce students' concentration in the classroom. Therefore, technology increases students' attention in the teaching and learning process (Hale \& Lewis, 1979; Thirkettle \& Pike, 2016). Students' inability to focus during the teaching and learning process tends to affect their ability to absorb the material (Bester \& Brand, 2013)

However, in teaching mathematics, the use of technology is essential to help students understand definitions, facts, operations, and theorems. Some cognitive factors that affect students' ability to learn Mathematical concepts are spatial attention, executive function, executive working memory, and controlled attention. (Aarnoudse-Moens, Weisglas-Kuperus, HJ, van, \& Oosterlaan, 2013; Bull, Espy, \& Wiebe, 2008; LeFevre, et al., 2013; Geary, 2010)

Article History: Received 4 May $2020 \bullet$ Revised 2 July $2020 \bullet$ Accepted 4 July 2020

(C) 2020 by the authors; licensee Modestum. Open Access terms of the Creative Commons Attribution 4.0 International License (http://creativecommons.org/licenses/by/4.0/) apply. The license permits unrestricted use, distribution, and reproduction in any medium, on the condition that users give exact credit to the original author(s) and the source, provide a link to the Creative Commons license, and indicate if they made any changes. 
According to Goldin (2002) and Sutton and Kruger (2002), students' mathematical beliefs and perception also affect their learning ability. For example, if students presume that mathematics is a complicated subject, it tends to affect their interest in learning the subject. A continuous increase in this negative thought leads to adverse effects, which affects their academic achievement (Loades, Clark, \& Reynolds, 2014), mathematics learning outcome (Op't Eynde, De Corte, \& Verschffell, 2002) and sometimes the associated subjects (Ja'faruddin, 2010). Negative activities affect students' beliefs and perceptions about their mathematics teacher or mathematics lesson (Ja'faruddin, 2014a).

Hypnotic suggestions are used in the teaching and learning process for students to control their "unconscious" drive and focus on the teaching and learning process (Ja'faruddin, 2012). Ja'faruddin (2012) stated that hypnoteaching is used to maximize students' subconscious mind during the learning process.

Hypnoteaching is the term used to define the application of hypnosis in the teaching and learning process (Ja'faruddin, 2010). It is traditionally defined as a highly focused state, which is sometimes marked with relaxation and a high level of suggestibility. However, in terms of educational purposes, Burrows G., Stanley, R., and Bloom, P (2001) defined it as an alternative state of awareness that enables students to selectively focus, absorb, and concentrate upon particular suggestions to achieve set educational goals. Meanwhile, teaching is an instructional process that involves the implementation of strategies and methods relative to particular situations and contexts, which enables learners to achieve set outcomes (Spielberger, 2004, p. 539).

Children are more likely to be inducted into the hypnotic state than adults (Spielberger, 2004). This means that the use of the hypnosis technic in teaching helps students to achieve high performance. In addition, a combination of hypnosis and teaching in education provides strong motivation needed to improve educational students' achievement.

Hypnoteaching helps students to control their mind through suggestion and facilitation (Hamzah \& Ja'faruddin, 2019). Hypnoteaching can be achieved by facilitating student's engagement in the teaching and learning process, improving their self-concepts of mathematics and yielding positive changes on their attitude and perceptions of mathematics (Asteria, Rohmah, \& Renhoran, 2017; Ja'faruddin, 2010, 2012, 2014a, 2014b; Sari \& Prihatnani, 2018; Zuhri \& Sukarnianti, 2015). There is a high probability that students can achieve unconscious competence when learning mathematics (Goldberg, 2006).

The basic principle of hypnoteaching is the subconscious mind program. Gunawan (2007) stated that the subconscious mind is programmable, with similar features as the computer terms of reinstallation, modification, or changing with new programs. Kahija (2007) and Gunawan (2007) stated that using Hypnosis is one of the ways to access the subconscious mind. Golberg (2007) stated that hypnosis can facilitate the ability to change and improve many things in a person's life, such as the ability to solve problems and enhance academic performance. Therefore, by conducting hypnoteaching, students' motivation can be maintained during the teaching and learning process.

Since 2008, several studies have been conducted on the positive effects of hypnoteaching models in the teaching and learning process of some subjects such as mathematics (Ja'faruddin, 2014a, 2014b, 2012, 2010). Asteria, Rohmah, and Renhoran (2017) reported that using hypnoteaching in Bahasa class made the teaching and learning process conducive, safe, and comfortable. Zuhri and Sukarnianti (2015) also stated its positive effect on students' writing ability. Sari and Prihatnani (2018) reported that hypnoteaching models tend to improve students' learning outcomes and confidence in mathematics.

The development of hypnoteaching models was inspired by the hypnosis and hypnotherapy theories developed by Erickson (1980) and Elman (1977). Erickson's Hypnoteaching Model uses metaphorical techniques through analogies and stories unrelated to student problems. This technique tends to affect students' motivation without any rejection due to critical thinking. The suggestion will be accepted by the student's unconscious mind because the messages are embedded in the analogues and stories. According to Erickson, indirect suggestion such as metaphor and case study tends to bypass conscious criticism and becomes more effective than a direct suggestion (Erickson \& Rossi ,1980; Haley, 1973). Erickson believed that indirect suggestion is a 'significant factor' in their research (Erickson, Rossi, \& Rossi, 1976). This technique also emphasizes the language patterns used in providing suggestions. Students need to note body language, attitude, and words used by teachers. (Ja'faruddin, 2010, 2014).

Elman's progressive relaxation induction and direct method inspired the development of the Elman-HM (Ja'faruddin, 2010; 2014). This is a therapeutic process used to induce someone, thereby making the body feel relaxed and comfortable. This technique has been severally modified from the original; however, it still consists of three components, namely relaxation of the body, mind, and deep rest (Elman, 1977). 
Table 1. Summary of two types of Hypnoteaching models

\begin{tabular}{lll}
\hline Hypnoteaching components & Erickson-Hypnoteaching Model Elman-Hypnoteaching Model \\
\hline Build rapport & Pacing and leading & Agreement Frame \\
\hline "Genius" anchor & Anchor, audio & Anchor audio \\
\hline Environmental learning & Group, discussion, presentation & Group, discussion, presentation \\
\hline "energizer" anchor & Audio, kinesthetic & Audio, Kinesthetic \\
\hline $\begin{array}{l}\text { Unconscious writing through mind } \\
\text { mapping }\end{array}$ & $\begin{array}{l}\text { Reformulate understanding, } \\
\text { making mind map and Cornell note }\end{array}$ & $\begin{array}{l}\text { Reformulate understanding, } \\
\text { making mind map and Cornell note }\end{array}$ \\
\hline reflection through relaxation & Imagining their brain is similar to & $\begin{array}{l}\text { Relaxation and suggesting that all } \\
\text { the material can be understanding } \\
\text { a computer, save all data }\end{array}$ \\
& & and recalling easily. \\
\hline
\end{tabular}

A typical hypnoteaching consists of six steps: (1) building rapport, (2) Genius anchor, (3) environmental learning, (4) energizer anchor, (5) reformulate understanding, and (6) reflection through relaxation (Ja'faruddin, 2010, 2012, 2014a, 2014b).

The first step: Building rapport is the process of creating a connection with students. In hypnoteaching, it is associated with pacing and leading, which was developed by Bandler and Grinder in 1979. This powerful model also utilized Erickson's technique (Bandler \& Grinder, 1975). The second technique of building rapport is an agreement frame inspired by Dave Elman, which results in the tremendous agreement students through relaxation and suggestion (Elman, 1977, Ja'faruddin, 2014).

The second step is associated with the activation of a genius anchor, which is the most important and unique step in learning. The genius anchor is an emotional button that helps students to access their best emotional state by triggering positive emotion. This step distinguishes motivation conditions from other teaching and learning approaches. The formation of anchors is also essential in programming students' subconscious minds. An anchor is a stimulus that triggers a certain feeling or emotion (Steve \& Vickers, 2004). In the Ericson Hypnoteaching model, the genius anchor is formed by the anchoring procedure and the hypnosis condition in the Elman Hypnoteching model. The anchoring procedure in the hypnoteaching model forms the first meeting of the experimental classes.

The third step: This tends to organize the learning environment in a way that is perfect for group work, and for teachers and students to carry out the question and answer principles while learning. The teacher facilitates students in internalizing the material. Furthermore, when the students' conditions start to look less enthusiastic, it is necessary to trigger an anchor that makes them fresh and enthusiastic. However, it is sometimes difficult to form an energizer anchor; therefore, teachers need to lead students during the first meeting of the mathematics class.

The fourth step: The energizer anchor is used to keep students focused and motivated during the learning and teaching process. The anchor formed was similar to the model mentioned in the second step.

The fifth step: Assimilate the acquired learned knowledge through mind mapping (Buzan \& Buzan, 1993) and note taking (Pauk \& Owens, 2005). Properly constructed teaching techniques help students to evaluate their understanding and mathematical ideas (Forman, McCormick, \& Donato, 1998). It also engineers a suitable learning environment for students to actively involved in the teaching and learning process (Lewis \& Tsuchida, 1998).

The last step reflects the teaching and learning material, which is conducted in a relaxed manner. The teacher guides students to enter the relaxed conditions and reflect on the material that they studied in the classroom. This last step needs to be closed by a positive suggestion to strengthen "learning" and the "genius anchor."

Table 1 shows the summary of the two types of Hypnoteaching models.

\section{OBJECTIVES OF THE STUDY}

The main purpose of this study is to investigate students' mathematics achievement and motivation using two different Hypnoteaching models, namely Elman-HM and Erickson-HM. The research sample consists of grade XII students of a Senior High School in South Sulawesi province, Indonesia. The research objective of this study are as follows: 1) to investigate the Students' achievement level in mathematics between the two experimental groups and a control group 2) to investigate the students' motivation level in mathematics 
Table 2. Research Design

\begin{tabular}{ccccccc}
\hline \multirow{2}{*}{ Time } & \multicolumn{9}{c}{ Model } \\
\cline { 2 - 7 } & $\begin{array}{c}\text { Erickson-Hypnoteaching } \\
\text { Model }\end{array}$ & $\begin{array}{c}\text { Elman-Hypnoteaching } \\
\text { Model }\end{array}$ & $\begin{array}{c}\text { Conventional non- } \\
\text { hypnoteaching model (CM) }\end{array}$ \\
\hline $\mathrm{Y}_{1}$ & $\mathrm{Y}_{2}$ & $\mathrm{Y}_{1}$ & $\mathrm{Y}_{2}$ & $\mathrm{Y}_{1}$ & $\mathrm{Y}_{2}$ \\
\hline $\mathrm{X}$ & $\mathrm{X}$ & $\mathrm{X}$ & $\mathrm{X}$ & - & - \\
\hline $\mathrm{O}$ & $\mathrm{O}$ & $\mathrm{O}$ & $\mathrm{O}$ & $\mathrm{O}$ & $\mathrm{O}$ \\
\hline
\end{tabular}

$\mathrm{Y}_{1}$ - mathematics achievement test

$\mathrm{Y}_{2}$ - students' motivation questionnaire

$\mathrm{X}$ - Treatment

$\mathrm{O}-$ Observation

amongst the three groups; 3) to compare the mathematics achievement and motivation between the experimental and the control groups.

\section{METHOD}

A quasi-experiment was conducted on three classes of senior high school students using two experimental groups and one control group. The study was conducted by manipulating variables by providing treatment to two groups in class XII IPS. After the standardized test was implemented, the three learning groups showed no significant differences in the basic knowledge of exponent numbers, when compared $\left(m_{\exp I}=4.86, S D_{\exp I}=\right.$ $0.27 ; m_{\exp I I}=4.80, S D_{\exp I}=0.45 ; m_{\text {control }}=4.53, S D_{\text {control }}=0.69 ; \mathrm{P}=0.38$ ). The simple random sampling technique was used by tossing a coin to assign the experimental and control groups. To make those groups comparable, a standardized test on basic concepts in exponent numbers were given to the students. The variables observed in this study were students' mathematics learning achievement and motivation. All groups were given the same topic on the concept of exponent numbers, operation in exponent numbers, and problemsolving. This covered the class meetings 16 times in the pretest and posttest groups with three teaching hours.

The treatment for group I (exp I) was mathematics teaching and learning process through Erickson-HM, and group II (exp II) was given treatment by Elman-HM. In contrast, the control group implemented conventional non-hypnoteaching model (CM) by exposing a purely lecture-discussion method using chalk and board.

Both experimental groups were exposed to six hypnoteaching steps, namely: (1) building rapport (2) "Genius" anchor (3) Environmental learning (4) "energizer" anchor (5) reformulate understanding (6) reflection through relaxation. The differences between the teaching and learning process using Erickson's and Elman's Hypnoteaching models were mentioned in the introduction. In the first meeting of the experimental groups, the researcher provides some explanations on hypnoteaching, misunderstandings of hypnosis, and the steps used to form genius and energizer anchor. The final process is the application and evaluation of the anchors. The Elman method uses direct suggestions and progressive relaxation methods, while Erickson applied indirect suggestion and fast induction methods.

The hypnoteaching processes in both classes were started in the second meeting, which covered three teaching hours ( $3 \times 45$ minutes). The first five minutes was used to build rapport and genius anchor, and for the last 10 minutes, it was for reflection through relaxation. The rest of the allocated time was for step four to five.

This research made use of quantitative data on mathematics achievement tests and students' motivation questionnaire. The mathematics achievement tests measured the students' ability in exponent numbers, while the motivation questioner was used to determine their choices (Likert scale modification) (Ruslan, 2009). Before the use of tests and questionnaires, the validity and reliability tests were conducted.

Data were analyzed with one-way ANOVA to determine the differences. Before the data analysis was performed, the Normality, Homogeneity, and Equivalence of the Matrix of Covariance Test scores were applied to the mathematics learning achievement test data and students 'motivation. The hypothesis testing on the mean cell parameter vectors was based on the Linear Multivariate Model by Wilks' Lambda ( $\Lambda)$. This was used to determine the differences in students' achievement and motivation in learning mathematics (Johnson, 2002, p. 299). 
Table 3. Summary of the results of the descriptive analysis of learning motivation scores in mathematics

\begin{tabular}{cccc}
\hline \multirow{2}{*}{ Category } & \multicolumn{3}{c}{ Percentage } \\
\cline { 2 - 4 } & Exp I (Erickson-HM) & Exp II (Elman-HM) & Control Group (CM) \\
\hline Subjects & 15 & 13 & 15 \\
\hline very low & $0.00 \%$ & $0.00 \%$ & $13.33 \%$ \\
low & $13.33 \%$ & $15.38 \%$ & $60.00 \%$ \\
high & $46.67 \%$ & $38.46 \%$ & $6.67 \%$ \\
very high & $40.00 \%$ & $46.15 \%$ & $20.00 \%$ \\
\hline Motivation level & High & High & Low \\
\hline
\end{tabular}

Table 4. Descriptive analysis of mathematics learning achievement

\begin{tabular}{cccc}
\hline Statistics & Models & Group III \\
\cline { 2 - 4 } & $\begin{array}{c}\text { Group I } \\
\text { (Erickson-HM) }\end{array}$ & $\begin{array}{c}\text { Group II } \\
\text { (Elman-HM) }\end{array}$ & $\begin{array}{c}\text { Grout } \\
\text { Control Group (CM) }\end{array}$ \\
\hline Subjects & 15 & 13 & 15 \\
Ideal Score & 100 & 80 & 80 \\
Highest score & 98.75 & 100 & 76.25 \\
\hline Lowest score & 55 & 26.25 & 26.25 \\
Score Range & 43.75 & 73.75 & 50 \\
Average score & 78 & 62.78 & 49.16 \\
Standard deviation & 10,287 & 16,371 & 9,193 \\
\hline Category & High & Medium & 0 \\
poor & 0 & 0 & 12 \\
less proficient & 0 & 4 & 2 \\
proficient & 2 & 5 & 1 \\
very proficient & 9 & 1 & 0 \\
excellent & 4 & & 0
\end{tabular}

\section{RESULTS AND DISCUSSIONS}

The research characteristics of the respondents in mathematics learning and achievement, represented by the motivation data, are analyzed using the descriptive statistics.

Table 3 shows that $40 \%$ of students in the experimental group I (Erickson-HM) and 46.15\% in II (ElmanHM) experienced very high motivation. This number is, however, double the percentage of students in the Control group at $20 \%$. On the other hand, the control group has $13 \%$ of students at a deficient motivation level, whereas the experimental has none. This finding indicates that applying the hypnoteching model in mathematics teaching and learning affects students' motivation.

Table 3 shows that 2 of students in exp I and 2 in Exp II are categorized as low-level motivation. However, these numbers are lower than those in the control group. The research observation shows that the procedure is used to form the genius and energizer anchors of these students in two experimental groups. Furthermore, their physical gestures did not indicate that they are in a deep relaxation state to fulfill the forming of genius and energizer anchor successfully. This means the students were unable to follow the steps associated with the hypnoteaching process in their groups.

Table 4 shows some impressive results of mathematics learning achievement between the three groups. Although group II (Elman-HM) had a maximum score of 100, in Group I (Erickson-HM), students obtained the highest average score of 98.75. Meanwhile, the students in the last position of Group III (control) had the least average score. The above data shows that the score range of group II is higher than the other two groups (73.75). This implies that there is a large discrepancy between the highest and lowest scores in the class experiment. Furthermore, the table shows that $13(86.67 \%), 6(46 \%)$ and 1 student in groups I, II, and control experienced a proficient and excellent level of mathematics achievement. It is interesting to note that no student in the experimental group using Erickson's hypnoteaching model was at a poor level.

Tables 3 and 4 show that all the experimental groups' motivation levels are at a high level in terms of students' achievements, with varying results using the Erickson-HM and Elman-HM models. The EricksonHM took the position in the high level of mathematics achievement while a student in the experimental class 
Table 5. Summary of Hypothesis Test

\begin{tabular}{|c|c|c|c|c|}
\hline Hypotheses testing & Mean Difference & $\boldsymbol{F}$ & $\boldsymbol{P}$ & Decision \\
\hline \multicolumn{5}{|c|}{ General hypothesis Tests } \\
\hline $\begin{array}{l}\text { One path Analysis manova (Wilks' } \\
\text { Lambda }(\wedge))\end{array}$ & $x^{2}+2+2+2$ & 7.3 & 0.00 & $\mathrm{H}_{0}$ Rejected \\
\hline $\begin{array}{l}\text { a one-way bivariate response variable } \\
\text { for mathematics learning achievement }\end{array}$ & & 13.583 & .000 & $\mathrm{H}_{0}$ Rejected \\
\hline \multicolumn{5}{|c|}{ Post Hoc Test-LSD results } \\
\hline Exp. I vs Control & $\left.28.844^{*}\right)$ & - & .000 & $\mathrm{H}_{0}$ Rejected \\
\hline Exp. II us Control & $13.62\left(^{*}\right)$ & - & .023 & $\mathrm{H}_{0}$ Rejected \\
\hline Exp.I vs. Exp. II & $\left.15.222^{*}\right)$ & - & .012 & $\mathrm{H}_{0}$ Rejected \\
\hline
\end{tabular}

Note: * Significant to $\propto=0,05$

by Elman hypnoteaching model was at the medium level. Further explanation is detailed by statistics inferential shown in Table 5.

The results of data analysis using one-way ANOVA shows that the value of Wilks' Lambda $(\wedge)$ F-statistic at 7.3 is higher than F-table at (2.48) or the p-value of $0.00<\alpha=0.05$. Therefore, $\mathrm{H}_{0}$ is rejected. Therefore, there are differences in students' achievement and motivation in learning mathematics between the Erickson and Elman's Hypnoteaching Models. Furthermore, the hypothesis test's analysis showed that the cell model's univariate parameter uses a one-way bivariate response variable to confirm the result. This means there are differences between the three groups in terms of mathematics learning achievement.

Table 5 also illustrates the Post Hoc Test-LSD result to determine the differences between groups. The students' achievement in experimental group I (by Erickson-HM) is significantly higher than those in the control group. This is supported by Table 2, with a mean of 78 compared to 9.16. This result implies that applying Erickson's Hypnoteaching model improves students' achievement.

A similar result also occurs when comparing the Elman-HM (exp II) and conventional non-hypnoteaching model (control group). However, the mean differences are lower compared to the previous, which means it provides a significant mark that Elman Hypnoteaching method is better than the conventional.

The steps in hypnoteaching make students focus on achieving learning purposes and providing a suitable environmental situation that makes them control their thought in the teaching and learning process (Hamzah \& Ja'faruddin, 2019) creating a positive learning experience and meaningful learning. Steps 1,2 and 4 resulting positive emotion and condition for students during the mathematics teaching and learning process. The learning environment in Step 3 encourages students in mathematics teaching and learning process. This allows students to construct knowledge through internalization of the materials. Further, Step 5 in both models allow student to strengthen their understanding by reformulating or rewriting what they have just learnt. And finally, closing by the reflection of the mathematics materials in the final step in a relaxed manner through positive suggestion further contributes to both comprehension and a good experience.

Hypnoteaching uses the hypnosis principle in the teaching and learning processes. Goldberg (2006) stated that there is a high possibility of getting unconscious competence by using hypnosis. Some previous research's results support this finding (Asteria, Rohmah, \& Renhoran, 2017; Ja'faruddin, 2014a, 2014b, 2012, 2010; Sari \& Prihatnani, 2018; Zuhri \& Sukarnianti, 2015).

Other factors that make significant differences in terms of students' achievement in learning mathematics are the suggestions provided by the models. Erickson's hypnoteaching model suggests the use of metaphors or stories strengthened by directly anchoring technique that affects students' subconscious minds (Erickson \& Rossi, 1980). Meanwhile, the Elman-HM also provides direct suggestions to the students, supported by the anchoring technique (Elman, 1977). These suggestions do not occur in the conventional model of the teaching and learning process.

Furthermore, the table shows that students' achievement in mathematics learning in Erickson's hypnoteaching model is significantly better than those in Elman-HM because it uses the indirect teaching method. This method makes students accept the suggestion without any rejection. Erickson \&Rossi (1980) stated that indirect suggestion is more effective. 


\section{CONCLUSIONS}

The hypnoteaching models are generally better than the conventional non-hypnoteaching model (CM) in enhancing students' mathematics achievement and motivation. Although there is no significant difference in students' motivation between the two hypnoteaching models, their level of mathematics achievement using Erickson-HM is better than Elman's Hypnoteaching Model. This is because it is in the high category, while Elman-HM is in the medium and the conventional model at the lowest level. It is evident that Hypnoteaching models improve student's motivation and facilitate students to construct their mathematical knowledge by providing a suitable environment for meaningful learning and leading to positive emotions resulting in achievement in mathematics.

\section{Disclosure statement}

No potential conflict of interest was reported by the authors.

\section{Notes on contributors}

Ja'faruddin - Universitas Negeri Makassar, Indonesia and Tunghai University, Taiwan.

Hamzah Upu - Universitas Negeri Makassar, Indonesia.

Chen Wen-Haw - Tunghai University, Taiwan.

Daniel Chia-En Teng - Tunghai University, Taiwan.

\section{REFERENCES}

Aarnoudse-Moens, C., Weisglas-Kuperus, N., HJ, D., van, G. J., \& Oosterlaan, J. (2013). Executive Function and IQ Predict Mathematical and Attention Problems in Very Preterm Children. PLoS ONE, 8(2), e55994. https://doi.org/10.1371/journal.pone.0055994

Asteria, P. V., Rohmah, S. K., \& Renhoran, F. Z. (2017). Penerapan Metode Hypnoteaching dalam Pembelajaran Bermain Peran Siswa Kelas V SDN Lidah Kulon IV Kecamatan Lakarsantri Surabaya. Jurnal Pendidikan (Teori dan Praktik), 2(2), 150-155. https://doi.org/10.26740/jp.v2n2.p150-155

Bandler, R., \& Grinder, J. (1975). Patterns of the Hypnotic Techniques of Milton H. Erickson, M.D. Vol. I. Cupertino, CA: Meta Publications.

Bandler, R., \& Grinder, J. (1979). Frogs into Princess. Moab, UT: Real People Press.

Bester, G., \& Brand, L. (2013). The effect of technology on learner attention and achievement in the classroom. South African Journal of Education, 33(2), 1-15. https://doi.org/10.15700/saje.v33n2a405

Bull, R., Espy, K. A., \& Wiebe, S. A. (2008). Short-Term Memory, Working Memory, and Executive Functioning in Preschoolers: Longitudinal Predictors of Mathematical Achievement at Age 7 Years. Developmental Neuropsychology, 33(3), 205-228. https://doi.org/10.1080/87565640801982312

Burrows, G., Stanley, R., \& Bloom, P. (2001). International Handbook of Clinical Hypnosis. Chichester, UK: John Willey \& Sons Ltd.

Buzan, T., \& Buzan, B. (1993). The Mind Map Book: How to Use Radiant Thinking to Maximize your Brain's. London: BBC Books.

David, A. O., \& Peter, W. (2009). Hypnotic suggestion and cognitive neuroscience. Trends in Cognitive Sciences 13(6), 264-270. https://doi.org/10.1016/j.tics.2009.03.004

Elman, D. (1977). Hypnotherapy. Glendale, US: Westwood Publishing Co.

Erickson, M. (1980). Method employed to formulate a complex story for the induction of an experimental neurosis in a hypnotic subject. In E. L. (ed.), The Collected Papers of Milton H. Erickson on Hypnosis, Vol. 3: Hypnotic Investigation of Psychodynamic Processes (pp. 26-33). Irvington, New York.

Erickson, M. H., Rossi, E. L., \& Rossi, S. I. (1976). Hypnotic Realities: The Induction of Clinical Hypnosis and Forms of Indirect Suggest. Irvington, New York.

Erickson, M., \& Rossi, E. (1980). Indirect forms of suggestion. In E. L. Rossi, The Collected Papers of Milton H. Erickson on Hypnosis: Vol. 1 The Nature of Hypnosis and Suggestion (pp. 452-477). Irvington, New York. 
Forman, E. A., McCormick, D., \& Donato, R. (1998). Learning what counts as a mathematical explanation. Linguistics and Education, 9(4), 313-339.

Geary, D. C. (2010). Mathematical disabilities: Reflections on cognitive, neuropsychological, and genetic components. Learning and Individual Differences, 20(2), $130-133$. https://doi.org/10.1016/j.lindif.2009.10.008

Goldberg, B. (2006). Self Hypnosis. Yogyakarta, Indonesia: B-First.

Goldin, G. (2002). Beliefs: a hidden variable in mathematics education? In G. Leder, W. Pehkonen, \& G. E. Torner, Affect, meta-affect, and mathematical beliefs structures. (pp. 59-72). London: Kluwer Academics Publisher.

Gunawan, A. W. (2007). Hypnosis The Art of Subconscious Communication. Jakarta, Indonesia: Gramedia Pustaka Utama.

Hale, G., \& Lewis, M. (1979). Attention and Cognitive Development. New York, US: Plenum Press.

Haley, J. (1973). Uncommon Therapy: The Psychiatric Techniques of Milton H. Erickson, M.D. Norton, New York.

Hamzah, U., \& Ja'faruddin. (2019). The Application Hypnoteaching in Mathematics Education. The 3rd International Conference on Statistics, Mathematics, Teaching and Research. Makassar, Indonesia: FMIPA UNM Makassar.

Hockly, N. (2011). The digital generation. ELT Journal, 322-325.

Ja'faruddin. (2010). Unconscious Mind Program (hypnoteaching) dalam Pembelajaran Matematika (Unpublished Thesis), Universitas Negeri Makassar, Makassar, Indonesia.

Ja'faruddin. (2012). Penerapan Unconscious Mind Program (Hypnoteaching) dalam pembelajaran Matematika. Jurnal Wadah Komunikasi, 5(3), 1-7.

Ja'faruddin. (2014a). Aplikasi Unconscious Mind program Di Universitas. National Seminar, ISBN: 979-604148-0 (pp. 31-40). Makassar: Universitas Negeri Makassar.

Ja'faruddin. (2014b). Hypnoteaching as A Teaching Model. International Conference on Mathematics, Science, Technology, Education and Their Application; ISBN:979-604-151-0. Makassar: Universitas Negeri Makssar.

Johnson, R. A. (2002). Applied Multivariate Statistical Analysis. New Jersey, US: Prentice-Hall, Inc.

Kahija, Y. L. (2007). Hipnoterapi. Jakarta, Indonesia: Gramedia Pustaka Utama.

Kihlstrom, J. F. (2007). Hypnosis. In C. D. Spielberger, Encyclopedia of Applied Psychology (pp. 243-248). Florida, USA: Elsevier Science.

LeFevre, J.-A., Berrigan, L., Vendetti, C., Kamawar, D., Bisanz, J., Skwarchuk, S.-L., \& Smith-Chant., B. L. (2013). The role of executive attention in the acquisition of mathematical skills for children in Grades 2 through 4. Journal of Experimental Child Psychology Journal of Experimental Child Psychology 114, 243-261. https://doi.org/10.1016/j.jecp.2012.10.005

Lewis, C., \& Tsuchida, I. (1998). A lesson is like a swiftly flowing river: Research lessons and the improvement of Japanese education. American Educator, 22(4), 14-17, 50-52.

Loades, M., Clark, S., \& Reynolds, S. (2014). Managing negative thoughts:positive imagery, self-talk, thought stopping and thought acceptance. Retrieved on 31 May 2020 from https://researchportal.bath.ac.uk/en/ publications/managing-negative-thoughts-positive-imagery-self-talk-thought-sto

Lytras, M., Gasevic, D., Ordonez de Pablos, P., \& Huang, W. (2008). Technology Enhanced Learning: Best Practices. New York: IGI Publishing.

Nurinda, Y. (2008). The secret of Stage Hipnosis Revealed. Retrieved June 13, 2009, from www. Hipnotis.net: www.Hipnotis.net

Op’t Eynde, P., De Corte, E., \& Verschffell, L. (2002). Framing Student's Mathematics-Related Beliefs: A Quest for Conceptual Clarity and a Comprehensive Categorization”. In G. Leder, W. Pehkonen, \& G. E. Torner, Beliefs: A Hidden Variable in Mathematics Education?. (pp. pp.13-37). Netherlands: Springer.

P. Morgan, W., \& Stegner, A. J. (2012). Hypnosis in sport: cases, techniques and issues. In The Oxford Handbook of Hypnosis Theory, Research and Practice (pp. 681-696). New York, the United States: Oxford University Press.

Pauk, W., \& Owens, R. J. (2005). How to Study in College. Boston, New York: Houghton Mifflin Company. 
Ruslan. (2009). Studi Tentang Kinerja Dosen Berdasarkan Kepuasan Mahasiswa dan Pengaruhnya terhadap Prilaku Pascakuliah di FMIPA Universitas Negeri Makassar (Unpublished Doctoral Dissertation). Makassar, Indonesia: PPS Universitas Negeri Makassar.

Sari, F. D., \& Prihatnani, E. (2018). Application Of Hypnoteaching Method To Improve SelfConfidence And Results Of Student Mathematic Learning. Journal of Educational Research and Evaluation, 2(4), 172182. Retrieved from https://ejournal.undiksha.ac.id/index.php/JERE

Smaldino, S., Lowther, D., \& Russell, J. (2008). Instructional Technology and Media for Learning (9th ed). Upper Saddle River, NJ: Pearson Publications.

Spielberger, C. D. (2004). Encyclopedia of Applied Psychology. Florida, USA: Elsevier Academic Press.

Steve, B., \& Vickers, A. (2004). NLP for Personal Success. Yogyakarta, Indonesia: Pustaka Baca.

Sutton, J., \& Kruger, A. (. (2002). ED Thoughts: What We Know About Mathematics Teaching and Learning. Aurora. Aurora, Colorado: Mid-continent Research for Education and Learning.

Thirkettle, M., \& Pike, G. (2016). Is technology making your attention span shorter than a goldfish's?. Retrieved from Phys.org website: http://phys.org/news/2015-05-technology-attention-span-shorter-goldfish.html

Zuhri, M., \& Sukarnianti. (2015). Using Hypnoteaching Strategy to Improve Students' Writing Ability. Dinamika Ilmu, 15(2), 185-199. Retrieved from https://journal.iainsamarinda.ac.id/index.php/dinamika_ilmu/article/view/101/199 